\title{
Characterization and thermogravimetric analysis of oil shale from Uvurjargalant deposit
}

\author{
Khulan Bayasgalan*, Myagmargerel Bayanmunkh, Ulzii Baatar, Bolormaa Bayarkhuu, \\ Tuya Murneren
}

Institute of Chemistry and Chemical Technology, Mongolian Academy of Sciences, $4^{\text {th }}$ Building of MAS, Peace Avenue, Bayanzurkh district, Ulaanbaatar, 13330, Mongolia

*Corresponding author: khuland88@gmail.com; ORCID ID:0000-0002-2438-9757

Received: 08 October 2018; revised:29 December; accepted: 31 January 2019

\begin{abstract}
The yield, properties and composition of soluble and insoluble (kerogen) of organic matter of oil shale from Uvurjargalant deposit of Mongolia have been investigated in this study. The study result shows that oil shale contains low amount of moisture and volatile products, while the ash yield is high $(71.86 \%)$ - which implies that most of the oil shale are minerals. The total amount of bitumens in the oil shale was very low (1.27 wt \%), whereas kerogen content was 22.84 wt \%, which is relatively high compared to oil shale from other deposits in Mongolia. Under IR spectral analysis and the ratio of hydrogen and carbon, the Uvurjargalant oil shale belongs to I type of oil shale. The thermogravimetric analysis showed that organic matter of oil shale decomposed at a temperature $300-750^{\circ} \mathrm{C}$ to produce gas and liquid products.
\end{abstract}

Keywords: oil shale, bitumen, thermogravimetric, kerogen

\section{INTRODUCTION}

Oil shale belongs to group of sapropel source containing organic matter and minerals and it is composed of clay and thin layers containing organic matter in the form of kerogen. Oil shale decomposes due to heat and produces a certain amount of liquid and gas products. Oil shale represents a large hydrocarbon resource from which energy can be recovered. The hydrocarbon constituents in shale rock are known as kerogens are formed by sedimentation of organic matters. The kerogen is contained within the interstices of the shale rock matrix and is generally about $15-25$ weight percent of the rock. The kerogen is typically converted into shale oil by high temperature processing of shale. Shale rock also contains other valuable inorganic minerals such as uranium, copper, nickel, cobalt, molybdenum, vanadium, titanium, iron and aluminum [1].

The organic matter in an oil shale is mostly in the form of kerogen, which is defined as that fraction of the organic matter in a sedimentary rock that is insoluble in common petroleum solvents. The insolubility of kerogen is the main reason why an oil shale must be heated to produce liquid products. The amount of shale oil that can be produced by heating oil shale is normally determined by a Fischer assay. However, the
Fischer assay is somewhat time-consuming and does not provide information about what chemical properties of oil shales are important for producing liquids. Consequently, a number of alternative procedures have been developed to analyse oil shales [2, 3]. Further study of the characteristics and chemical composition of the oil shale is crucial to the development of techniques for producing synthetic liquids and the creation of new energy sources. Geological studies indicate that the total resources amount to 11319.6 million tons of oil shale covering about 60 deposits in Mongolia [4]. This makes it imperative to study the possibilities of exploitation and processing of oil shale.

The aim of this study is to evaluate the chemical and technological properties of oil shale from Uvurjargalant deposits from Mongolia by using thermogravimetric and chemical composition studies and technical analysis.

\section{EXPERIMENTAL}

Materials: in this study, we used oil shale sample of 0.2 - $0.5 \mathrm{~mm}$ granules, obtained from a depth of 0.8-1.5 $\mathrm{m}$ of Uvurjargalant deposit in Erdenetsant subdivision, which is located $260 \mathrm{~km}$ from Ulaanbaatar to the West in Mongolia. The sample was crushed, sieved and dried at $105^{\circ} \mathrm{C}$. 
Experimental procedures: Soluble organic matter or bitumen $(A)$ of oil shale was extracted with chloroform solvent and insoluble organic matter (kerogen) was treated with a concentrated $\mathrm{HCl}$ and $\mathrm{HF}$ solutions (1:1). After that it was washed with saturated boric acid solution. Kerogen was dried at a temperature of $80^{\circ} \mathrm{C}$, bitumen $(C)$ was extracted from organic residue using ethanol-benzene (1:1) solvent.

Elements of the sample $(\mathrm{C}, \mathrm{H}, \mathrm{N}$ and $\mathrm{O})$ were determined by the Vario EL III analyser. Thermogravimetric analysis, pyrolysis of oil shale from 25 to $1050^{\circ} \mathrm{C}$ at heating rate of $10^{\circ} \mathrm{C} \mathrm{min}$ m $^{-1}$ for 120 min was carried out by analyser (HITACHI TG/DTA7300 apparatus from Japan) using argon as a purge gas. The experiments were carried out using about $10 \mathrm{mg}$ with $0.2 \mathrm{~mm}$ granules analytical sample in a platinum crucible. Approximately 10 grams of oil shale was crushed to prepared powder samples, which were analysed using the Wavelength Dispersive X-ray fluorescence spectroscopy (WDXRFS).

\section{RESULTS AND DISCUSSION}

The results of the analysis of moisture, volatile matter and composition of bitumens in the oil shale samples from Uvurjargalant and other deposits are shown in the table below.

The results of the study reveal that moisture and volatility are relatively low, and ash yield is high due to fact that the oil shale has high mineral content.

Table 1. Proximate analysis and composition of bitumens of Mongolian oil shale (wt \%)

\begin{tabular}{lllll}
\hline & $\begin{array}{l}\text { Uvur } \\
\text { jargalant }\end{array}$ & $\begin{array}{l}\text { Tuhum } \\
\text { Lake [5] }\end{array}$ & $\begin{array}{l}\text { Bil jis } \\
{[5]}\end{array}$ & $\begin{array}{l}\text { Khuut } \\
\text { bulag [5] }\end{array}$ \\
\hline Total moisture & 1.94 & 2.05 & 3.33 & 3.4 \\
Volatile matter & 24.74 & 14.75 & 26.62 & 24.60 \\
Ash content & 71.86 & 83.2 & 70.05 & 72.0 \\
Bitumen A & 0.52 & 0.23 & 1.0 & 0.47 \\
Bitumen C & 0.75 & 0.26 & 0.9 & 0.39 \\
Kerogen & 22.84 & 13.08 & 4.18 & 11.12 \\
\hline
\end{tabular}

The content of the organic matter in the oil shale is between $10-70 \%$ in wt \%, of which $90-95$ in wt \% are kerogens. Kerogens do not dissololve in organic solvents and are usually composed of aromatic and aliphatic compounds. The content of bitumen $A$ and bitumen $\mathrm{C}$ in the oil shale is relatively low, but it is almost twice as high in Uvurjargalant's deposit as compared to the deposits of Tukhum lake and Khuutbulag deposits in Mongolia. The content of kerogen in Uvurjargalant oil shale was $22.84 \mathrm{wt} \%$ which is a higher than other shale deposits previously studied [5].

Based on the elemental analysis of Uvurjargalant's oil shale, the contents of carbon and hydrogen in bitumen A are $76.8 \%$ and $11.73 \%$, respectively. The content of sulfur and nitrogen in bitumens $(A, C)$ and kerogen in the studied oil shale is relatively small and the content of
Table 2. Elemental compositions of Uvurjargalant's oil shale, wt \%

\begin{tabular}{lccccccc}
\hline \multirow{2}{*}{ Sample } & \multicolumn{4}{c}{ Content, wt \% } & \multicolumn{3}{c}{ Ratio } \\
\cline { 2 - 8 } & $\mathbf{C}$ & $\mathbf{H}$ & $\mathbf{N}$ & $\mathbf{S}$ & $\mathbf{O}$ & $\mathbf{H} / \mathbf{C}$ & $\mathbf{O} / \mathbf{C}$ \\
\hline Bitumen A & 76.80 & 11.73 & 0.26 & 1.25 & 9.96 & 1.83 & 0.63 \\
Bitumen C & 67.20 & 9.39 & 0.78 & 1.95 & 20.68 & 1.67 & 0.31 \\
Kerogen & 66.79 & 9.67 & 1.59 & 1.41 & 26.54 & 1.70 & 0.30 \\
\hline
\end{tabular}

oxigen is relatively higher. Higher hydrogen content, low sulfur and nitrogen contents in the oil shale composition have the advantages of producing liquid products by liquefaction process.

The type and origin of kerogen is determined depending on the results of elemental analysis of kerogen in oil shale. According to studies and researches, I type of kerogen has a high ratio of $\mathrm{H} / \mathrm{C}(\sim 1.5$ or more), low ratio of $\mathrm{O} / \mathrm{C}(<0.1)$, and is composed of lipid component containing hydrocarbons with aliphatic chains. Due to the fact that I type kerogen is high lipid content, it is believed that its origin is derived from the residue of the plant, or derived from organic matter via treatment of microorganisms (Krevelen diagram) [6, 7].

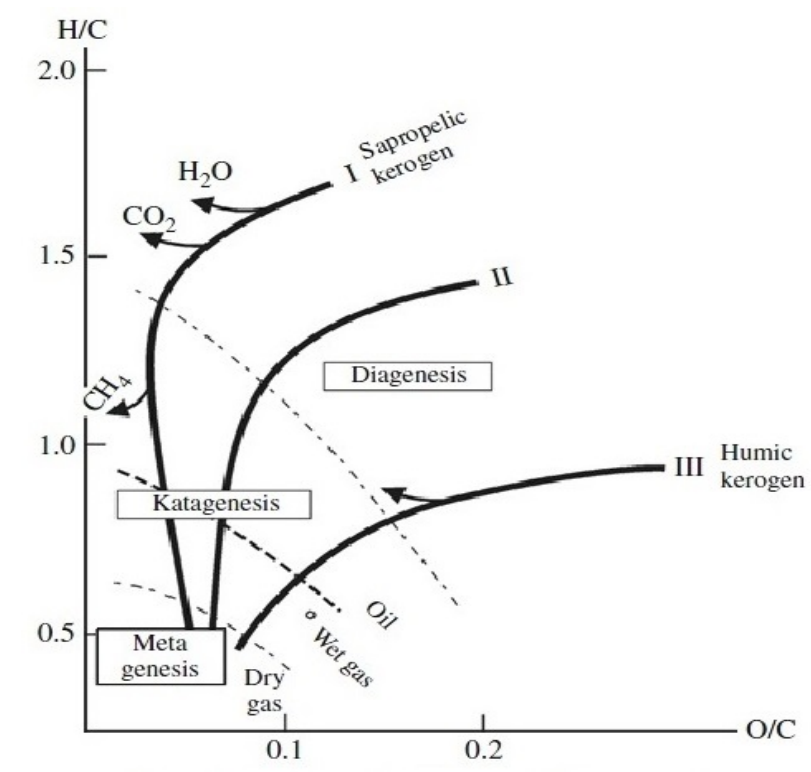

Fig.1. Van Krevelen diagram of kerogen type

According to the results of elemental analysis of kerogen in the oil shale, the ratio of carbon and hydrocarbons atoms $(\mathrm{H} / \mathrm{C}, \mathrm{O} / \mathrm{C})$ in Uvurjargalant's oil shale is classified as I type. Such a type of oil shale contains comparatively less heteroatoms and polyaromatic compounds compared to other types of oil shale.

In addition, significant amounts of oxygen (9.96 - 26.54 wt \%) and high ratio of $\mathrm{O} / \mathrm{C}(\mathrm{O} / \mathrm{C}-0.3)$ in sample oil shale could be the result of a long-term oxidation process on the surface area. 


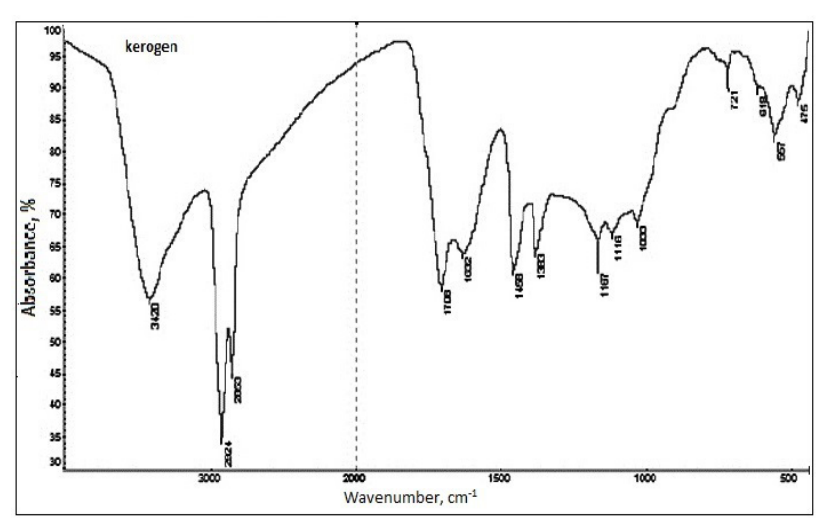

Fig. 2. IR spectrum of kerogen in Uvurjargalant oil shale

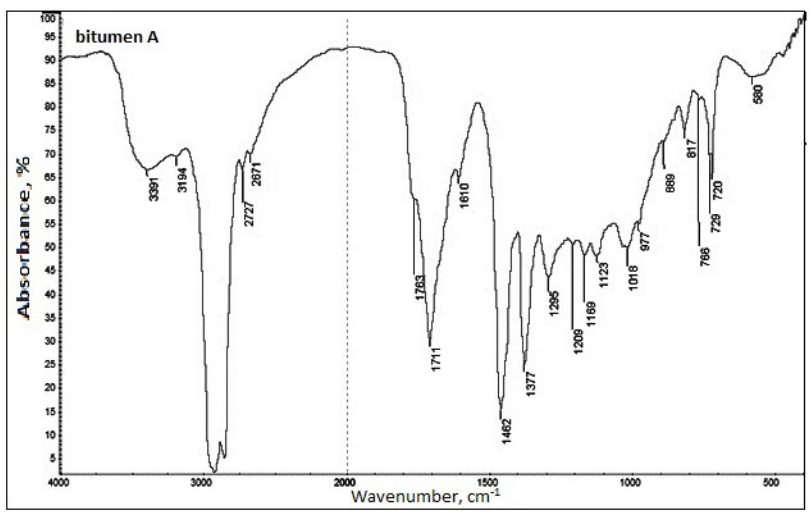

Fig. 3. IR spectrum of bituminous A extracted from Uvurjargalant's oil shale

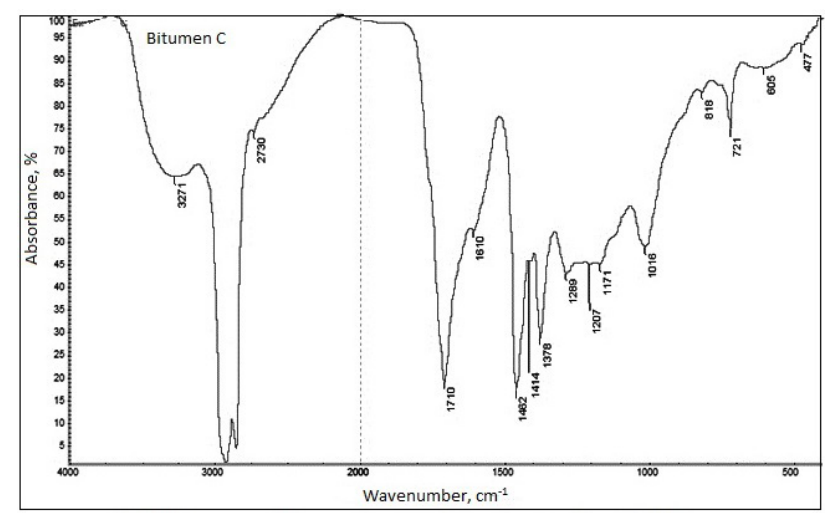

Fig. 4. IR spectrum of bituminous $\mathrm{C}$ extracted from Uvurjargalant's oil shale
The structure of the hydrocarbons in the composition of bitumen A, C and kerogen, separated from Uvurjargalant's oil shale, was determined by IR spectroscopy and is shown in Figure 2 - 4.

IR analysis for whole bitumens and kerogen showed characteristic bands at $2853-2980 \mathrm{~cm}^{-1}$. The bands are related to $\mathrm{CH}$ - aliphatic. The IR spectrum of kerogen shows the followings bands; wider absorption lines of $-\mathrm{OH}$ of phenol and ethanol groups at $3400 \mathrm{~cm}^{-1}$, absorption lines of $\mathrm{C}=\mathrm{O}$ of carbonyl group in ethanol, ketones and carboxylic acids and ether in $1708 \mathrm{~cm}^{-1}$, $\mathrm{C}=\mathrm{C}$ in the aromatic chain at $1600-1630 \mathrm{~cm}^{-1}$, absorbtion lines of the rings of the $\mathrm{C}_{3}$ and $\mathrm{C}_{2}$ groups at $1458 \mathrm{~cm}^{-1}$, absorption width lines of $\mathrm{C}-\mathrm{O}$ and $\mathrm{OH}$ groups at 1165$1033 \mathrm{~cm}^{-1}$. In addition, further spectra IR with band peaks at $1458-1383 \mathrm{~cm}^{-1}$ showed intensity lines of the cluster group in the aromatic ring. The IR spectrum of bitumens $A$ and $C$ shows intensive absorptions for which $\mathrm{C}=\mathrm{O}$ groups of carbonyl, ketone, carboxylic acid, $\mathrm{C}=\mathrm{O}$ groups in aliphatic groups $\left(\mathrm{CH}_{2}\right.$ and $\left.\mathrm{CH}_{3}\right)$ with long chain and at 2900-1710 $\mathrm{cm}^{-1}$ [8]. IR spectral analysis has shown that oxygen-containing groups, such as a carboxyl, carbonyl and ketones are predominate in the oil shale's kerogen and bitumen, proving that this oil shale belongs to the Type I of the plant [6].

The Uvurjargalant oil shale mainly comprises majority of the silicon oxide $\left(\mathrm{SiO}_{2}-47.27 \%\right.$ mass fraction) and a minumum of iron and calcium and magnesium oxide at $5.33-18.11 \%$. The result of the study showed that basic elements of silicates such as $\mathrm{Si}, \mathrm{O}, \mathrm{Al}, \mathrm{Fe}^{3+}$, $\mathrm{Mg}, \mathrm{Mn}, \mathrm{Ca}, \mathrm{Na}, \mathrm{K}$ are contained in the composition of oil shale, meaning that the oil shale is belongs to the silicate group. The oil shale ash with high a content of $\mathrm{SiO}_{2}$ is a good raw material for producing high strength artificial ceramsite. It can also be used for producing cement and other building materials when mixed with other ingredients [9].

Thermogravimetric analysis is used to estimate the yields of solid, liquid and gas products from thermal decomposition which was done in conditions of high temperature and different gas flow. In the near future, it is important to study in detial the physico-chemical processes that occur during thermal decomposition, depending on impacts such as the temperature, gas flow and the time of the process [10]. The thermogravimetric (TG) curve was created by measuring the mass change of sample using thermogravimetric apparatus during

Table 3. The mineral compositions of the Uvurjargalant oil shale, wt \%

\begin{tabular}{lllllllllll}
\hline $\mathrm{Fe}_{2} \mathrm{O}_{3}$ & $\mathrm{SiO}_{2}$ & $\mathrm{Al}_{2} \mathrm{O}$ & $\mathrm{TiO}_{2}$ & $\mathrm{As}_{2} \mathrm{O}_{3}$ & $\mathrm{BaO}$ & $\mathrm{CaO}$ & $\mathrm{MgO}$ & $\mathrm{Cr}_{2} \mathrm{O}_{3}$ & $\mathrm{CuO}$ & $\mathrm{Na}_{2} \mathrm{O}$ \\
\hline 5.33 & 47.27 & 14.46 & 0.59 & 0.06 & 0.08 & 18.11 & 4.63 & 0.02 & 0.01 & 1.66 \\
\hline $\mathrm{K}_{2} \mathrm{O}$ & $\mathrm{Mn}_{3} \mathrm{O}_{4}$ & $\mathrm{P}_{2} \mathrm{O}_{5}$ & $\mathrm{SO}_{3}$ & $\mathrm{PbO}$ & $\mathrm{ZnO}$ & $\mathrm{V}_{2} \mathrm{O}_{5}$ & $\mathrm{Cl}$ & $\mathrm{Br}$ & $\mathrm{SnO}_{2}$ & $\mathrm{WO}_{3}$ \\
\hline 2.63 & 0.18 & 0.61 & 0.64 & 0.13 & 0.02 & 0.47 & 0.07 & 0.41 & 0.02 & 0.01 \\
\hline
\end{tabular}




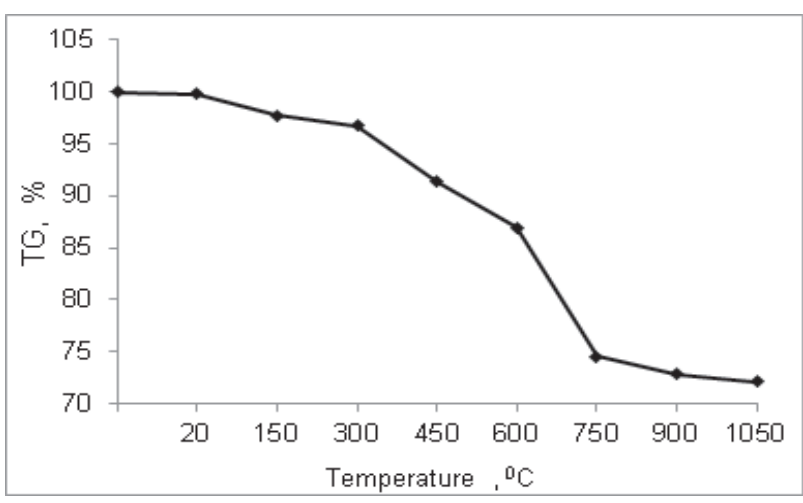

Fig. 5. The thermogravimetric (TG) curve for mass loss of Uvurjargalant's oil shale during thermal decomposition process

the thermal decomposition process under argon gas. The TG curve in Figure 5 shows that the pyrolysis of Uvurjargalant oil shale goes througth two stages of mass loss. The evaporation of moisture and decomposition of weak chemical bonds occur in the initial stage at 20 $300^{\circ} \mathrm{C}$. The creation of liquid mass by decomposition of bitumen and kerogen, present in the oil shale, occur in the second stage at a tempurature of $300-750{ }^{\circ} \mathrm{C}$. Clay type compounds in the oil shale had decomposed most intensively. The above analysis shows that the mass loss is up to $26.78 \%$ at the temperature of $750^{\circ} \mathrm{C}$. Basically, decomposition is complete at $750-1050^{\circ} \mathrm{C}$, and the residue occurs in a cooking process. The study found that the ideal temperature for extracting liquid products from the shale is $300-750^{\circ} \mathrm{C}$. DTAs and DTA curves of the thermogravimetric analysis are described by thermal mechanisms of the oil shale and heat effects of reaction. The curve of differential thermodynamic analysis (DTA) is created by measuring the effects of the heat generated by continuous heating in inert gas [11]. According to the DTA curve, thermal decomposition of the oil shale is a process of endotherm and the main stage of the decomposition at $300-750^{\circ} \mathrm{C}$ is more intense. When the residual polymerization process

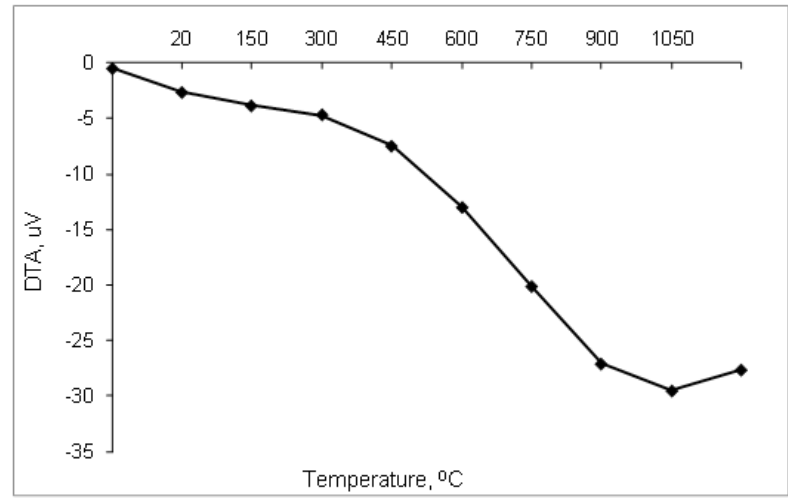

Fig 6. The curve of thermodynamic analysis (DTA) of Uvurjargalant's oil shale

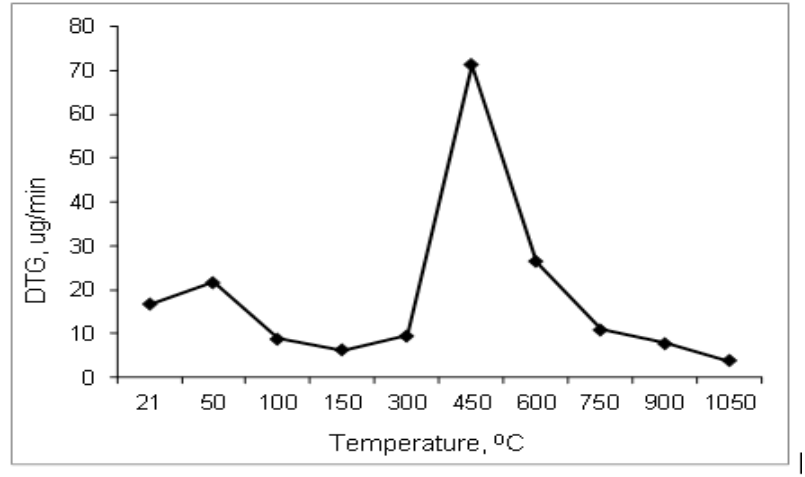

Fig. 7. The curve of thermogravimetric analysis (DTG) of Uvurjargalant's oil shale

occurrs at $900-1050{ }^{\circ} \mathrm{C}$, the heat absorption process decreases. Various chemical processes, such as decomposition, oxidation, and polymerization occur as a result of thermal decomposition, and the mass change in the processes is expressed as a differential thermogravimetric curve (DTG). According to the thermogravimetric (DTG) curve of the oil shale, the initial peak is associated with the release of gas and moisture of the oil shale at temperature of $20-150{ }^{\circ} \mathrm{C}$, and the major DTG peak at $300^{\circ} \mathrm{C}-750^{\circ} \mathrm{C}$ corresponds to the release of gas and liquid products. It has been shown in the study that the maximum velocity of the decomposition of organic matter in the oil shale is at $450^{\circ} \mathrm{C}$.

Uvurjargalant oil shale has not been studied before and this study shows that the oil shale belongs to kerogen Type I. In terms of geological origin, this type of oil shale is basically derived from a seaweed plant source [6]. The Uvurjargalant oil shale has a relatively high bitumen and kerogen content compared to other shale deposits in Mongolia [5]. Therefore, it is possible to produce liquid product and synthetic crude oil from the oil shale.

Our research result can have a potentially high practical and economic significance for investigating and exploiting prospective oil shale technology in terms of recent studies of Uvurjargalant oil shale, since the study focused on the determining the oil shale resource and the possibility extracting of oil from oil shale.

\section{CONCLUSION}

Chemical compositions and thermogravimetric analysis of Uvurjargalant oil shale from Mongolia were invesgated for the first time through the study. The results of study show that the content of bitumens in the oil shale was very low $(0.52-0.75 \%)$, whereas the content of kerogen was $22.84 \%$. Elemental composition of kerogen and $\mathrm{H} / \mathrm{C}$ ratios, as determined in the study, reveal that the oil shale belonges to kerogen Type I (sapropelic kerogen). The decomposition of organic mass in the oil shale occurred at $300-700{ }^{\circ} \mathrm{C}$, is the 
most intense, and the mass loss is $26.78 \%$ and the study has proven that liquid products can be produced through thermal decomposition.

\section{REFERENCE}

1. William F. Wolff and John D., McCollum. (1987) Method for treating shale. USA, Patent 4668380

2. Miknis F.P., Netzel D.A. (2006). Oil shale and shale oil analysis. In: Encyclopedia of Analytical Chemistry (eds Meyers R.A., Nick P.A). doi:10.1002/9780470027318.a1830m

3. Surech Bhargava, Fires Awaja, Nalaka Deepal Subasinghe (2005) Characterisation of same Australian oil shale using thermal, X-ray and IR techniques. J. Fuel, 84(6), 707-715. doi:10.1016/j. fuel.2004.11.013

4. Tuya M., Golovko A.K., Khulan B., Namhainorov J., Ulzii B., Chantsaldulam G., Khongorzul B. (2016) Study of chemical composition of Mongolian oil shale. Bulletin of ICCT, 3, 66-73. (in Mongolian)

5. Savelev V.V., Pevneva G.S., Namkhainorov J., Golovko A.K. (2013). Oil shales of Mongolia. J. Solid Fuel Chemistry, 45(6), 397-403. doi:10.3103/ $\underline{\text { S0361521911060127 }}$
6. Tisso B. (1981) Oil shale. Mir, Moscow, Russia, 501 (In Russian).

7. Hutton A., Bharati S., Robl T. (1994) Chemical and petrographical classification of kerogen/ macerals. Energy Fuels, 8(6), 1478-1488.

8. Anderson R.G., Bendell D.J., Groundwater P.W. (2004) General principles. In: Abel E.W (ed) Organic Spectroscopy Analysis, Cambridge. elSBN:978-1-84755-156-6.

9. Wei Wang, Shuyuan Li, Linyue Li, Yue Ma, Changtao Yue, Jilai He. (2014) Pyrolysis characteristics of North Korean oil shale. Petroleum Science, 11(3) 432-438. doi:10.1007/s12182-014-0358-x

10. Jargalmaa S., Tsatsral G., Battsetseg M., Batkhishig D., Ankhtuya A et al. (2017) Kinetic study of Mongolian coals by thermal analysis. Mong. J. Chem., 18(44), 20-23. doi.org/10.5564/ mic.v18i44.933

11. Fengtian Bai, Youhong Sun, Yumin Liu, Baochang Liu et al. (2014) Kinetic investigation on partially oxidized Huadian oil shale by thermogravimetric analysis. Oil Shale. 31(4), 377-393. doi:10.3176/ oil.2014.4.06 